Version read on Oct.11,1987 at the conference on 'Me'moires, historres, identute's' at Laral University Published with this tutle in the caurduan Journol of African Studies 23C2):232-249(1989

THA

$$
\begin{aligned}
& \text { A } \\
& \text { Willian } \text { J. Saramin } \\
& \text { University of Toronto }
\end{aligned}
$$

In the colonization of central Africa along the Congo ( $Q$ aire) and Ubangi rivers in the last. two decades of the nineteenth century whites recruited workers irrespective of the probiens that would arise from their ignorance of European languages and of the problems they would have in communicating with each other. If a potential worker kngw some English, French, or Fortuguese, as was frequently true of those reoruited on the west cosst, it was to his advantage; he got a better position and was paid more, Linguistio conpetence was not, of course, rewarded for its own sake. What counted was the work that the African could do, the The bilingual

role he could play) fre naturally was more valuable to whites than somene who knew only his own or some other African language. But the linguistic factor; it must be emphasized, was never a deciding one in a person's being hired for general work. There is no evidence whatsoever that restricted linguistic competence ever put an Africen at a disadvantage in recruitment. All that mattered was a person's willingness to work under the contract set by the white recruiting agent.

Whites obviously believed that communication sufficient for the basio needs coud be effected in one way or another. Every record of caravan trips fron the coast to Staniey Fool (Malebo) and every appointnent of a white to a position of leadership and responsihility soon after arrival in Africa is evidence of this fact. There was no "breaking-in" period for Belgian or French of ficials, for exanple (Gone whites, of course, sought to familiarize themselves with 
Congolese languages through voobularies that slowly became available, frequently on the whites

qoean voyage to Africa, They essuned responsibility as soon as they arrived in the field, wherever that might be. A survey of the biographies of a number of Belgian officers who went to the Uhangi region in 1892, for example, reveds that ir many oases only two nonthe had elapsed from the tine they left Ealgium to the time they took on duties in the field Ganarin

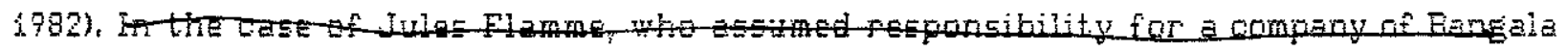

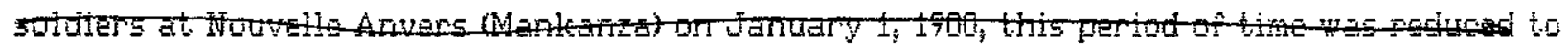

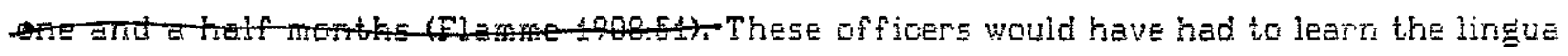
franca of the Force Publique, Bangela (now oalled Lingala), as well as to learn how to communicate with various ethric groups in the area.

Eecause whites in the 1880 and 1890 were moving about too frequertily because they were coming into contact with a wide variety of languages, and because they were overcone by host of daily tasks, they oould not acquire fluenoy in any of the indigenous that is, ethnio) languages. In this generalization number of differences are slighted aver. Traders and miscionaries, for example, may have stayed in one place longer than officers and representatives of the governments. And the similarities between all of the Bantu languages would have simplified learning something of a second or third after having learned ane. Nonetheless, by and large whites in central Africa, excepting Protestant missionaries perhaps, did not conoern themselves with the yernaculars if they could use the lingua Geovge

franoss. The Frotestant commitment to the vernaculars is ilustrated in Grenfell's comment Ebout language study at Lukolele: "Till the language is nastered (more than a mere colloquial acquaintance is necesseryl not much real work can be done. It is impossible in a country like this to get interpreters who are able to do nore than talk about the sinplest every-dey things, and then but very imperfeotiv" Missionary Herald 1989:469).

What whites could not do, their workers, many of them from distant lands, acoomplished. 
They were, after all, the ones who cane in closest contact with the indigenous ponulations, and it was they who executed the will of the whites This African internediary could be anyone, but anvone (1) who shared a language with the white, (2) who enjoyed aertain enount of trust, and (3) who could be presented to others as representing the white. A soldier was eninently qualified for this role, but it coudd just as well be, and very frequently was, ihe white's personal servant. Known as boy in odonial pariance, he usually was indeed a orild, less

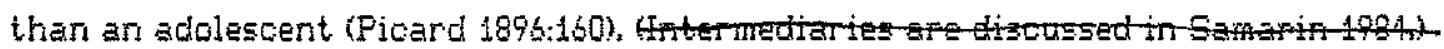

Whites give the orders, blecks did the work. Out of this work - in this work context emerged the lingua francas that are today known as Kituba (or Munukutuba), Lingala, and Sango. They were new languages; oreated by Africans working together; so they were among the first of Africa's work languages.

\section{Colonial sompetence}

Competence in the use of African languages was variable anong whites. Sone applied themselves to acquiring enough to baragouiner their way through palavers, whereas others depended heavily on their interpreters. The impression they liked to leave with their fellow countrymen in Europe was that they got along very well, Coquiliat was one of these. In his memoirs, writing of the time when he recruited the first Bangala workers, he said: "w $j$ appris a perler couramment la langue, ce qui augmenta considerablement ma popularił́e et me donna la faculté de me mettre directement en rapports avec les personnes que je désirais entretenir. Dès ce noment. je connus tout ce qui se passait" (Coquilhat 1888:513), What makes us doubt his assertion is that he attributes great fluency to himself at. a tine when he had not been in the area for long enough to have nastered even a modest conversetional hnowledge Besides; he was, by hiz own statements, also learning Gwahil, Kiteke, and Kildo at the sane time, fute 
really too much to believe.

Whites in Eeneral could make proud clams about their linguistic competence, becuse they had very low opinions of African languages and a limited view of whet communiogtion in African larguages amounted to To start with, thoy nade a distinotion betwen speaking and understanding blacks. The letter was especially difficult if fot inoomprehencible, because it was such a "langue personäelle et. presque incomprehensibie dont usent les indigenes entre eux" observed ore and besuse blacks deliberately altered their speech out of mistrust for whites, observed another (La Eelgique Coleniale 1896:27\%; Ficard 1874:160), Speakine was assier beosus of the restricted vocebulary. Dr. Curesu, Gherving that the nost conplate dictionaries had about 500 words, attributed to Afrioan langueges about 2 , 500 to 3 , distinctes ${ }^{3}$ including all those words that one covid derive by affixation (Cureau 1012 :E2). Another estimate wes even lower. Eecause of the Africans' limited needs and rudimentary sentinents, neny whites believed, 300 words was more than necessary in communicating with Africans (Vauthier 1900214), whatever they thought the total vocabulary of Africars night. be, whites certainly were satisfied with a minimel one iñ scoomplishing what they wantefi Tith three litile vocabularies in the languges of the Upper Congo, one person dedared, voyager had all the indispensable elenents for making hingelf understodd by natives (Chanax 1894.56\%, Linguistic helps put together in the nineteenth century bonsisted of lists of words, ocosionally with phrases that a person might find usef ul. Whites must have thought that the languages had no grammar, or that the grammar was revealed in the way they the whites, put words sogether. In any case, it was true as late as 1925 that whites, with the exoeption of missionaries, as one observer remarked, were still learning African words but not African grannar (Torday 1925:179).

Whites would not have devoted thenselves with any seriousness to the acquigition of vernaculars, because there guickly emerged three lingua frances that permitted then to have 
contact with a certain number of the indigenous peoples: varigties of Kikongo, Bangala, and Sango. Because these were new languages, they would have had to be learned by the indigencus peoples; but because they were based on indigenous lenguages and were greatly sinplified. they were not difficult to acquire.

\section{The role of French}

The role of European languages in the period with which we are concerned was very limited, On the west coast some Africans had acquired a certain proficiericy in Portuguese, English, or Frenoh, a fact that made then very useful to whites. Some of these persons were quite young. It was reported, for example, that at Buanza, in the Lower Congo, there were children of 10 years who had been employed as errand-boys (commissionnaires) at Fortuguese, Englieh, and Frenoh trading posts who spoke these three languages "Easily" (Sand 169522), These multilinguals could serve as at least the first link in the communication chain whites had to establish with indigenous peopies, They were precious to whites, but they were few, However; they were not needed in large numbere during the periad when whites were getting gettled in central Africa. Although they were useful in any number, in many gituations only one was sựficient

Sohools, operated by missions, were conducted both in French and in some African language. There seeme to have been a difference between what took plate in the French Congo and what came to be the Belgian Congo. At French missions on the coast French was used (and even Fortuguese) (Sand 1895:22), on the Ubangi River, at Sainte Famille some French vas taught, According to one observer in 1900 the childsen at the mission had learned enough to act as interpreters with the local natives; acoording to another in 1905 children were learning "a little" French (Chapiseau 1900:192; Challave 1909:73). Although there is not much information about what actually happened in French mission schools, we certainly know the 
atitude of the Apostolic Vioar of the Ubangi, Mgr. Prosper Augouard. For hin the two "Essential colonial ideas" were the creation of indisenous labor and the diffusion of the French languege, a sentiment that was repeated by the exploren Jean Dybowski by whon work was defined $\Xi$ gujture du sol. For Mgr Augouard the teaching of French was the prinoipal, indeed, the only way of wining Africans over to whites (De Witte 1924 299; Dybowski 1912, oited in De witie 1924:43; of Bobichor 191222), The missionary attitude was this: "Les entante nous sont envovés pour que nous leur apprenions à ainer la France et à en parler la langue" Bulletin de 1a Congregation [CSE] 1902:706), fhis/poliov was different from that of the tirst. superior of the Holy Spirit Congregation, who froeded that natives would have to be tadeht. in their own orude (Erossier) speech, singe thetr lack of education made a nore eleveted. IEnguage incomprehensible to them (Eschbech $1874: 16$ ).

The Belgian policy favored the use of African languages. This was observed by one writer, who supported this renerk by adding that whereas not one civil servant spoke a native language in Brazzaville around 1900, in the Belgian Congo "tous les Elancs parlent une larigue indigène jusqu’à un certain poirt" (Torday 1925:201), Even though wa oan consider the statement as being exaggerated and inacourate to some degree, it probably suggestsa fundamental difference in linguistic practice and policy in the two colonies. I an inclined to believe that the little this writer had observed of the Free State was of whites using Bangala and vehigular Kikongo. This is seen in the statement that for some whites "il suffit d"un vocabulaire restreint; une sorte de sabir commeroial, pour entrer en relations avec les indigenes," the reason being that blacks have linited regds (Vauthier 1900214). At. Catholio niscions Frenoh was not apparentiy an important part of the progran of sohooling. The one Nolvelle Anvers at. Bangala for exampla was well endowed but as late as 1899 the languages that were taught. were "celles des Bangala et des Babangi [sic]" (Thonner 199717-19) . Mpowbu,

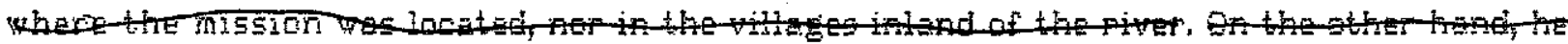


had a low opinion of the rive language fhat is lingua fransa Eangala, which he did not consider a true language. bith repeot to what was said above about whites and vernacular languages, we can note that in this Anark about "Ieal Bangala," Fr. De Boeck observed thet "Les blancs ne s'y fatiguent pas/"." This was in 1902) (Van den Bergh 1955:6).

Lenguage policy under the Beigians is a subject that requires a great deal of study. Ore view at the moment is that "Eelgian Catholio missionaries were strongly opposed to the use of French or any other modern European language by Africans" (Yetes 1780:262) it. is argued that Africans were prevented fron learning French in order that missionarias wight be able to keep batter control over them. Similarly, it is argued by another that in Katanga at any rate, French was carefully rationed for Africans and Swahili was encouraged ag "an effective, protective barrier against free communication [ketween blacks and whites]" (Fabian 1986:136). Although future work might require revision of sone aspects of these interpretations of the histary of Belgian Congo, we are obliged to grant that Erench did not. have an important role in the education that Congolese were gething in the Force Fublique and in mission schools.

That whitgs, including missionaries, were not all agreed about language poliov will be seen in the following statemert by the pioneer missionary, George Grenfell, of the Baptist Missionary Society. in 1895, in fesponse

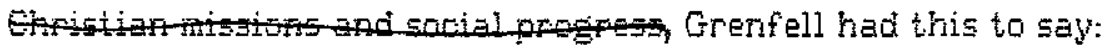

In addition to developing the self-reliance and resourcefulness of a more or less skilled body of artisans, the missionaries, by teaching them a bivilizad language and bringing then into contact with the literature and civilization of the world, have placed then in a position of great advantage, as compared with those among whon miscion work has been carried on exclusively in the language of the country. From a distinotly religious point of view, it may be detateable 
as to whether it is advantagede or not to teach a new languge, but from a social point of view the gain is very distinct...

Where the native tongue is alone the vehole for instruction and eomunication, the naintenanoe of the old trading monopolies of the hesd men, of the wide-embracing institution of slavery and the despotic cruelty of the oniefs, is secured for a much longer geriod than is possible where the people are anlightered through the mediun of avilized language, and thereby enabled to realize that they constitute part of the civilized world (Hawker 1909:389-390).

\section{SEmmary}

In communicating with their workers whites at first used coastal Africans who had acquired some proficiency in one or more of the European languages Outside of these few internediaries, most of whon were themselves workers of one sort or another, workers were not put together into workforces on the basis of linguigtio skills. The personnel of expeditions and of stations were ethrolinguistically very diverse. whites in general, missionaries exoepted, did not seen to becone conpetent in indigenous languages and favored the lingua franoas that emerged in the latter part of the rineteenth century These new languages energed out of the communication that was effected by expatriate blecks with indigenous peoples on the Congo and Ubangi rivers. Although they were oalled trede languages by whites, it was the total work context that led to their birth As indigenous peoples learned these lenguages, whites had contact with them, either directiy or through their bilingual underlings, in these languages. Work was supervised and skills taught by these work bosses (kapitas). Two of the lingua francas, Eangala and Sango, beome the principal languages of the militias. The colonial language, French, played a lese important role, and less for the Free State than for the French Condo. 